\title{
INTRODUCTION: THE POLITICS OF NONCOMPLIANCE
}

1. "Almost all nations observe almost all principles of international law and almost all of their obligations almost all of the time" (Henkin 1968, 479; italics in original).

\section{INFRINGEMENT DATA AND NONCOMPLIANCE}

1. For real icebergs, more than 90 percent is submerged.

2. Treaty provisions and regulations are generally binding and directly applicable, while decisions are administrative acts aimed at specific individuals, companies, or governments, for which they are binding.

3. Member states may also fail to comply with judgments of the court on the four types of violations. The EU's court is the final arbiter concerning violations of EU law. Its judgments are as legally binding as treaty provisions, regulations, directives, and decisions. Since they refer to cases of noncompliance with EU legal acts, they are reported as consecutive infringements of these legal acts, adding another stage to the infringement proceedings.

4. Thomson Reuters, CELEX, http://data.ellispub.com/ojolplus/help/celex.htm, last accessed 26 April 2020.

5. European Commission, Single Market Scoreboard, http://ec.europa.eu/internal_ market/scoreboard/performance_by_governance_tool/transposition/index_en.htm\#main contentSec4, last accessed 26 April 2020.

6. According to the doctrine of the éffet utile, developed by the ECJ, member states have to choose the most effective means, however (Case C-8/55 Fédéchar v. High Authority [1956] ECLI:EU:C:1956:11; C-26/62 Van Gend en Loos [1963] ECLI:EU:C:1963:1; cf. Dimitrakopoulos 2001).

7. The original title of the reports was Annual Report to the European Parliament on Commission Monitoring of the Application of Community Law.

8. See, e.g., Case C-29/59 Knutange v. ECSC High Authority [1960] ECR-00001.

9. See, e.g., Case C-294/83 Les Verts v. European Parliament [1986] ECR-01339.

10. The possibility of imposing financial penalties was dropped in the Treaty of Rome (1957) and only reintroduced by the Maastricht Treaty (1992). For the history of the infringement proceedings see Prete 2017.

11. Note, however, that, according to the view of the ECJ, the letter defines the object at issue in any subsequent court proceedings. As a result, the Commission is not allowed to include additional points during subsequent stages, even if it later discovers new infringements.

12. Case T-191/99 Petrie and Others v. Commission [2001] ECR II-3677: 67-68, drawing on Case T-105/95 WWF UK v. Commission [1997] ECR II-313.

13. The European Court of Justice is increasingly referred to as the Court of Justice of the European Union (CJEU). However, the CJEU denotes the entire court system of the EU, which includes the ECJ but also the General Court. Since the ECJ adjudicates infringement proceedings, I keep using ECJ. 
14. Case T-191/99 Petrie and Others v. Commission [2001] ECR II-3677, drawing on Case T-105/95 WWF UK v. Commission [1997] ECR II-313 and Case T-309/97 Bavarian Lager Company v. Commission [1999] ECR II-3217.

15. The fine's basic amount of $€ 640$ per day is multiplied by a factor $n$, taking into account the GDP of a member state and its number of votes in the Council. The factor $n$ for Luxembourg, for instance, is 1 and for Germany 21.12 (Commission of the European Communities 2012b).

16. For a similar argument on the ECJ as strategic enforcer see Blauberger and Schmidt 2017; Carrubba 2005; Carrubba, Gabel, and Hankla 2008; Fjelstul and Carrubba 2018; and Larsson and Naurin 2016. Their findings demonstrate that the ECJ is selective in its rulings but do not reveal that this results in a bias toward certain member states or policy sectors.

17. Commission official, interview with the author, Berlin, 30 May 2013.

18. The questionnaires and the results of the two surveys are available from the author on request.

19. Eszter Zalan, “Juncker Rebukes Hungary's EU Commissioner," EUobserver, 2 December 2015, https://euobserver.com/institutional/131353, last accessed 29 August 2020.

20. Case C-6/64 Flaminio Costa v. E.N.E.L. [1964] ECR 614.

21. Case C-26/62 Van Gend en Loos [1962] ECR 001.

22. Case 43/75 Defrenne v. Sabena [1976] ECR 455.

23. Case C-144/04 Mangold v. Rudiger Helm [2005] ECR I-9981.

24. I owe this term to Beth Simmons.

25. EUR-Lex, “About EUR Lex," http://eur-lex.europa.eu/content/welcome/about.html? locale=en, last accessed 27 August 2020.

26. Dimiter Toshkov, "Data and Replication Materials," http://www.dimiter.eu/Data. html, last accessed 29 April 2017.

27. From 1984 until 2010, data in the annual reports accounted only for any "new steps" taken in infringement proceedings in that year. Since 2011, annual reports have been limited to presenting aggregate data on selected topics. Finally, the newly introduced search engine on infringement decisions by the Commission is limited to a period starting in 2002 and, similarly, only provides for separate accounts of single decisions ("new steps")—which often precede the official issuing of the corresponding act within the infringement proceeding, as compared to the dates provided in earlier annual reports or on the ECJ's website CURIA.

28. The first year for which the Commission comprehensively collected and published infringement data was 1978; the most recent update of the BID was 7 March 2019. Since it takes on average two years for the Commission to send a reasoned opinion, I made the cut for asserted infringements in 2017.

29. EUR-Lex, "Access to European Union Law," http://eur-lex.europa.eu/homepage. html, last accessed 24 April 2020.

30. Pre-Lex does not exist anymore. The data was integrated in EUR-Lex, http://eurlex.europa.eu/collection/legislative-procedures.html?locale=en, last accessed 18 July 2017.

31. Cf. Case T-309/97 Bavarian Lager Company v. Commission [1999] ECR II-3217: 40.

32. In one particular case it took France about twenty years to comply with Council Regulation No. 2057/82 establishing certain control measures for fishing activities.

33. The graph shows the ratio of average annual infringements (1978-2012) to average annual adopted directives (1978-2009), according to policy sector. For infringements, the categorization of policy sectors is based on the Directorate-General of the European Commission leading the infringement proceeding. For directives, the policy indicator was hand coded on the basis of "directory code" data in the EUR-Lex database. However, the European Commission has undergone numerous changes in its internal structure, 
reflecting developments in both the nature and focus of EU policymaking over time. These changes have become more significant in recent years and thus present challenges to the continuation of the policy categories at hand. A notable example can be seen in the rearrangement of Directorate-General (DG) Health \& Consumers (SANCO) and DG Justice \& Home Affairs (JAIN) into the newly formed DGs for Health \& Food Safety (DG SANTE), Justice \& Consumers (DG JUST), and Migration \& Home Affairs (DG HOME). In most of these cases, the continued existence of similar configurations in other EU institutions - including both the Justice and Home Affairs Council (JHA) and the European Parliament's Committee on Civil Liberties, Justice and Home Affairs (LIBE) — as well as continued cooperation among the corresponding internal services of the Commission (cf. "Area of Freedom, Security and Justice") may justify keeping the original categorization of policy sectors. As opposed to former policy sectors being split at some point in time, however, the incremental integration of the long-standing Directorate-Generals for Internal Market and Services (DG MARKT) and Enterprise \& Industry (DG ENTR) constitutes a change in the available data (especially from 2014 onward), which cannot be easily resolved in the coding process. Accordingly, a continuation will either require strict indicators for the division of new infringements and directives into existing policy categories, or a fusion of both categories in line with the newly formed Directorate-General for Internal Market, Industry, Entrepreneurship and SMEs (DG GROW), which would in turn significantly reduce the degree of differentiation in an analysis of policy sectors. I have thus refrained from any further continuation of these statistics for the time being, instead only presenting secure data based on the original version of the Berlin Infringement Database (1978-2012).

\section{POWER, CAPACITY, AND POLITICIZATION}

1. Council Directive 91/271/EEC of 21 May 1991 concerning urban waste water treatment.

2. European Commission, "Commission Takes Italy Back to the Court and Proposes Fines," press release, 8 December 2016, http://europa.eu/rapid/press-release_IP-16-4212_ en.htm, last accessed 11 March 2019.

3. For the distinction between preferences over outcomes versus preferences over strategies in the literature on international cooperation see Stein 1983; Axelrod 1984; Oye 1986; Frieden 1999. Theories of international cooperation tend to refer to cooperation and defection rather than compliance and noncompliance as the two main strategies states can pursue to achieve their most preferred policy outcome.

4. Fearon refers to the two stages as the bargaining versus the enforcement phase (Fearon 1998). Shaping and taking go beyond his distinction most importantly by systematically incorporating domestic actors in both the bargaining and the enforcement of international and EU law.

5. The votes in the Council of Ministers are weighted according to a member state's population. Even though the system has been skewed in favor of smaller member states, France, Germany, Italy, and the UK as the four most populous member states have had almost ten times more votes than Malta, whose population is less than 0.05 percent of the German population. Under the double majority rule introduced by the Lisbon Treaty's ordinary legislative procedure, population size still matters. Each member state has only one vote now. However, majority decisions require 55 percent of member states representing at least 65 percent of the EU population (Article 238 TFEU).

6. A blocking minority requires three of the larger member states to join forces with one of the smaller member states. After Brexit, Spain and Poland have enough weight to substitute for the UK. 
7. The Lisbon Treaty summarizes the consultative, cooperation, and assent procedures under special legislative procedures and made the former co-decision procedure the ordinary legislative procedure (Article 294 of the Treaty on the Functioning of the EU).

\section{WHY SOME STATES COMPLY LESS THAN OTHERS}

1. Bergman 2000, Falkner et al. 2005, and Falkner, Hartlapp, and Treib 2007 put the UK and the Netherlands in the middle group. Lampinen and Uusikylä 1998, Haverland, Steunenberg, and van Waarden 2011, Haverland and Romeijn 2007, and König and Luetgert 2009 concur with regard to the Netherlands. Yet almost all these studies focus on timely transposition only.

2. The graph shows the annual ratio between new member states' infringements (according to reasoned opinions) and the mean number of infringements on behalf of the old member states during their first ten years of membership. As opposed to the average annual number of infringements per member state displayed in other statistics, the graph at hand also includes the year of accession, which has often been marked by a certain "grace period" and is clearly visible in the statistical outliers among countries such as Greece, Portugal, Spain, Malta, or Croatia.

3. The International Country Risk Guide, provided by the World Bank, has an indicator on rule of law or "law and order tradition," but it does not cover the full time period of my analysis (Kaufmann, Kraay, and Mastruzzi 2003). James L. Gibson and Gregory A. Caldeira's opinion poll survey retrieved data at only one point in time, 1992-1993 (Gibson and Caldeira 1996).

4. "Selon la Commission européenne, la Clause Molière est une 'discrimination," Le Figaro, 19 March 2017, https://www.lefigaro.fr/conjoncture/2017/03/19/20002-20170319ART FIG00054-la-clause-moliere-est-une-discrimination-estime-la-commission-europeenne.php, last accessed 28 August 2020.

5. Countries that receive funding from the Cohesion Fund, the EU established in 1993 have a gross national income per inhabitant of less than 90 percent of the EU average. After eastern enlargement, the only EU-15 member states that still qualify are Greece and Portugal.

6. Directive 2006/24/EC of the European Parliament and of the Council of 15 March 2006 on the retention of data generated or processed in connection with the provision of publicly available electronic communications services or of public communications networks and amending Directive 2002/58/EC.

7. BVerfG, Judgment of the First Senate of 02 March 2010-1 BvR 256/08-paras. (1-345).

8. See https://www.bmu.de/fileadmin/Daten_BMU/Download_PDF/Umweltin formation/aarhus_umsetzungsbericht_2013_korrektur_bf.pdf, last accessed 3 August 2020.

9. See chapter 4 for more details on the directive.

10. While EU opposition has been rather stable for most member states, Denmark and Italy have seen some substantial changes. In Italy, opposition more than tripled since 1999 (from 5 to 17 percent in 2010). In Denmark, it halved during the same period (from 24 to 12 percent). Greece saw a recent rise from 13 to 21 percent, probably due to the euro crisis.

\section{WHY THERE IS NO GROWING NONCOMPLIANCE}

1. The EU adopted "unity in diversity" as its official motto in 2000, https://europa.eu/ european-union/about-eu/symbols/motto_en, last accessed 3 September 2017. 
2. Commission Communication on "A Europe of Results-Applying Community Law," COM(2007)502 final, p. 1.

3. On the following see also Börzel and Buzogány 2019.

4. Once an infringement is "confirmed," a letter of formal notice is sent.

5. Suspected infringements were initially broken down into "complaints" and "cases detected by the Commission" by inquiries on its own initiative. In 1988, "parliamentary questions" and "petitions" were added to "cases detected by the Commission." In 1998, "cases detected by the Commission" became the overall category for "petitions," "parliamentary questions," and a residual category, which may refer to the Commission's own investigations. From 2006 to 2010, "cases detected by the Commission" were renamed as "own initiative cases." In 1996, the Annual Reports included a third category, next to complaints and cases detected by the Commission / own-initiative cases: the noncommunication of national measures transposing EU directives. Since 2011, the Commission only reports data on complaints and own initiatives as a total as done before 1988 . Noncommunication is relabeled as late transposition. Petitions and parliamentary questions are no longer listed separately. Finally, the Commission introduced "enquiries" as a separate category next to complaints. These changes take effect gradually, since old cases are recoded and partly recounted under the newly introduced categories. I therefore limit the analysis to data available for the years 1982-2010. Data on own investigations and noncommunication are available only since 1988 and 1996, respectively.

6. Commission Communication on Effective Problem Solving in the Internal Market (“SOLVIT”) COM(2001) 702 final.

7. European Commission, "Internal Market Information System," http://ec.europa. eu/internal_market/imi-net/about/index_en.htm\#maincontentSecl, last accessed 31 January 2020.

8. Commission Communication on "A Europe of Results-Applying Community Law," $\operatorname{COM}(2007) 502$ final.

9. Internal document of the Commission, unpublished but available from the author on request.

10. Commission official, interview with the author, Berlin, 30 May 2013.

11. The treaty establishing the European Coal and Steel Community had provided for the possibility of imposing financial penalties (Article 89). Articles 169-171 of Treaty of Rome dropped these provisions.

12. Case C-387/97 Commission v. Greece [2000] ECR I-5047.

13. The Commission closed the case on the Greek landfill in 2001-only to discover that Greece had not fully complied with the ECJ ruling. Instead of reopening the case, the Commission launched an infringement proceeding against a second illegal landfill close by (Hedemann-Robison 2015: 186, 199; Case C-112/06 Commission v. Greece [2006] OJ C121/4).

14. Commission Communication on the Application of Article 260 of the Treaty on the Functioning of the European Union. Updating of data used to calculate lump sum and penalty payments to be proposed by the Commission to the Court of Justice in infringement proceedings SEC(2010) 1371; cf. Peers 2012.

15. Commission Communication: Action Plan for the Single Market CSE(97)1 final.

16. For 1988-2005, tov_2 and tov_3 follow similar trajectories as their aggregates.

17. European Commission, Single Market Scoreboard, SOLVIT, http://ec.europa.eu/ internal_market/scoreboard/performance_by_governance_tool/solvit/index_en.htm\#main contentSec4, last accessed 8 September 2020.

18. Ibid.

19. European Commission, Single Market Scoreboard, EU Pilot, http://ec.europa. eu/internal_market/scoreboard/performance_by_governance_tool/eu_pilot/index_ en.htm\#maincontentSec4, last accessed 8 September 2020. 
20. For 1978-2008 see EU Budget 2008 Financial Report, http://ec.europa.eu/budget/ library/biblio/publications/2008/fin_report/fin_report_08_en.pdf, last accessed 10 December 2019. For 2008-2013, EU Commission Budget in Figures, http://ec.europa.eu/budget/ figures/index_en.cfm, last accessed 10 December 2019.

21. "Reinforcing the Effectiveness of the Internal Market. Working Document of the Commission on a Strategic Programme on the Internal Market" (Sutherland Report) COM (93) 256 final, Section IV, Enforcing the rules through partnership.

22. "A New Strategy for the Single Market: At the Service of Europe's Economy and Society," Report to the President of the European Commission José Manuel Barroso, 9 May 2010, https://www.kfw.de/migration/Weiterleitung-zur-Startseite/Homepage/KfWGroup/Research/PDF-Files/Monti_Report.pdf, last accessed 31 August 2020.

23. ECHA, European Chemicals Agency, "Enforcement Forum," http://echa.europa. eu/about-us/who-we-are/enforcement-forum, last accessed 27 August 2020.

24. Case 138/79 Roquette Frères S.A. v. Council [1980] ECR-03333.

25. The Treaty of Maastricht mentioned the role of national parliaments within the European Union in the nonbinding Declaration No. 13 (Declaration on the role of national Parliaments in the European Union [1992] OJ C191/1). The Amsterdam Treaty included a Protocol on the Role of National Parliaments in the European Union [1997] OJ C340/1.

26. Article 7 of Protocol No. 2 to the Lisbon Treaty on the application of the principles of subsidiarity and proportionality.

27. OE (Open Europe), "National Democracy Pushing Back: European Commission Shown Its Second Ever 'Yellow Card," 29 October 2013, http://openeuropeblog.blogspot. com/2013/10/european-commission-shown-its-second.html, last accessed 28 March 2020.

28. Unfortunately, there is no corresponding data on the directives in force. However, with an average transposition deadline of eighteen to twenty-four months, and another eighteen to twenty-four months it takes for an infringement to reach the official stage of a reasoned opinion, the cutoff points for directives adopted (2009) and reasoned opinions sent (2012) match.

29. Council Directive 92/43/EEC of 21 May 1992 on the conservation of natural habitats and of wild fauna and flora.

30. Council Directive 2006/112/EC of 28 November 2006 on the common system of value added tax.

31. EUR-Lex, Legal Acts, https://eur-lex.europa.eu/collection/eu-law/legislation/ recent.html, last accessed 6 March 2020.

32. Council Directive 92/43/EEC of 21 May 1992 on the conservation of natural habitats and of wild fauna and flora.

33. Council Directive 79/409/EEC of 2 April 1979 on the conservation of wild birds.

34. Council Directive 91/271/EEC of 21 May 1991 concerning urban waste water treatment.

35. Council Directive 85/337/EEC of 27 June 1985 on the assessment of the effects of certain public and private projects on the environment.

36. Council Directive 2006/112/EC of 28 November 2006 on the common system of value added tax.

37. Council Directive 92/50/EEC of 18 June 1992 relating to the coordination of procedures for the award of public service contracts.

38. Council Directive 93/37/EEC of 14 June 1993 concerning the coordination of procedures for the award of public works contracts.

39. Directive 2004/18/EC of the European Parliament and of the Council of 31 March 2004 on the coordination of procedures for the award of public works contracts, public supply contracts, and public service contracts. 
40. Council Directive 83/189/EEC of 28 March 1983 laying down a procedure for the provision of information in the field of technical standards and regulations.

41. Council Directive 88/182/EEC of 22 March 1988 amending Directive 83/189/EEC laying down a procedure for the provision of information in the field of technical standards and regulations.

42. Directive 2005/36/EC of the European Parliament and of the Council of 7 September 2005 on the recognition of professional qualifications.

43. EUR-Lex, http://eur-lex.europa.eu/legal-content/en/ALL/?uri=CELEX:31992L0043, last accessed 7 April 2020.

44. Directive 2006/123/EC of the European Parliament and of the Council of 12 December 2006 on services in the Internal Market.

45. "European Commission Shelves Olive Oil Jug Ban after Outcry," Euronews, updated 23 May 2013, https://www.euronews.com/search?query=European\%20Commission\%20 Shelves\%20Olive\%20Oil\%20Jug\%20Ban\%20after\%20Outcry, last accessed 28 August 2020.

\section{WHY NONCOMPLIANCE IS SECTOR SPECIFIC}

1. Directive 2004/38/EC of the European Parliament and of the Council of 29 April 2004 on the right of citizens of the Union and their family members to move and reside freely within the territory of the Member States, amending Regulation (EEC) No 1612/68 and repealing Directives 64/221/EEC, 68/360/EEC, 72/194/EEC, 73/148/EEC, 75/34/EEC, 75/35/EEC, 90/364/EEC, 90/365/EEC and 93/96/EEC.

2. For the purpose of identifying most infringed legal acts per policy sector, the number of infringements per legal act was calculated differently from identifying the most infringed directives in chapter 4 (table 4.4). Each infringement proceeding was attributed to a single legal act, namely the most recent directive. This method was employed in order to avoid double counting of one infringement proceeding, particularly with a view to the data used in the (directive-based) regression analysis. However, the method fails to take into account those infringements against a legal act where the proceeding concerned several acts and another CELEX number took precedence in the coding process. In identifying the most infringed legal acts per policy sector, this disadvantage becomes more significant, as all legal acts are considered (instead of directives only), and the singlecounting method would leave several infringed legal acts seem "untouched." For this reason, all CELEX numbers mentioned in an infringement proceeding (amounting to up to thirty different legal acts) were listed and counted, allowing us to account for all legal acts ever infringed, as well as the entire volume of infringements against a single legal act. However, it should be kept in mind that this method includes multi-counting, thus rendering any accumulation of the number of infringements against a certain "complex" of legal acts (e.g., consisting of several interconnected, supplementary, and amending directives; or of one treaty article changing its CELEX number over time) extremely problematic. At the same time, any double counting between policy sectors is precluded, as each ranking exclusively counts infringements in that same policy sector. For this purpose, the policy sector was identified on the basis of the infringement proceeding, not the legal act in question.

3. Directive 2006/24/EC of the European Parliament and of the Council of 15 March 2006 on the retention of data generated or processed in connection with the provision of publicly available electronic communications services or of public communications networks and amending Directive 2002/58/EC.

4. Directive 2008/99/EC of the European Parliament and of the Council of 19 November 2008 on the protection of the environment through criminal law.

5. Council Directive 79/409/EEC of 2 April 1979 on the conservation of wild birds. 
6. Directive 2009/147/EC of the European Parliament and of the Council of 30 November 2009 on the conservation of wild birds.

7. Council Directive 92/43/EEC of 21 May 1992 on the conservation of natural habitats and of wild fauna and flora.

8. The initial Directive of 1985 (85/337/EEC) and its three amendments have been codified by Directive 2011/92/EU of 13 December 2011. Directive 2011/92/EU was amended in 2014 by Directive 2014/52/EU.

9. Council Directive 91/271/EEC of 21 May 1991 concerning urban waste water treatment.

10. INSO was renamed Communications Networks, Content and Technology in 2016.

11. Directive 2002/22/EC of the European Parliament and of the Council of 7 March 2002 on universal service and users' rights relating to electronic communications networks and services.

12. Directive 2009/136/EC of the European Parliament and of the Council of 25 November 2009 amending Directive 2002/22/EC on universal service and users' rights relating to electronic communications networks and services, Directive 2002/58/EC concerning the processing of personal data and the protection of privacy in the electronic communications sector, and Regulation (EC) No 2006/2004 on cooperation between national authorities responsible for the enforcement of consumer protection laws.

13. Council Directive 93/13/EEC of 5 April 1993 on unfair terms in consumer contracts.

14. Directive 2005/29/EC of the European Parliament and of the Council of 11 May 2005 concerning unfair business-to-consumer commercial practices in the internal market and amending Council Directive 84/450/EEC, Directives 97/7/EC, 98/27/EC and 2002/65/ EC of the European Parliament and of the Council and Regulation (EC) No 2006/2004 of the European Parliament and of the Council ("Unfair Commercial Practices Directive").

15. Council Directive 1999/74/EC of 19 July 1999 laying down minimum standards for the protection of laying hens.

16. Somewhat similar to the scope is the concept of specializations (or the lack thereof), which is described by Steunenberg and Kaeding 2009 as "the extent to which directives regulate rather technical issues, which are intended to be implemented uniformly by national administrations" (11).

17. The dependent variable is the number of infringements per member state per year.

18. The dependent variable is the number of infringements per directive.

19. EU Vocabularies, https://op.europa.eu/en/web/eu-vocabularies/, last accessed 8 May 2020.

20. Council Directive 83/189/EEC of 28 March 1983 laying down a procedure for the provision of information in the field of technical standards and regulations.

21. Regulation (EU) 2015/2120 of the European Parliament and of the Council of 25 November 2015 laying down measures concerning open internet access and amending Directive 2002/22/EC on universal service and users' rights relating to electronic communications networks and services and Regulation (EU) No 531/2012 on roaming on public mobile communications networks within the Union.

22. Since the Maastricht Treaty and the Lisbon Treaty entered in force at the end of 1993 and 2009, respectively, we took the following year as reference point for calculating the age of a sector.

23. Customs Union falls under the exclusive competence of the EU, i.e., has the highest score in terms of level and scope. Taxation is exactly the opposite. Since it is hard to infringe on the EU's external tariffs, and all infringements in the sector concern Taxation, we drop Customs Union.

24. Until 6 September 2017, Germany accepted only 7,852 refugees of the 27,536 (2.5 percent) it had agreed to in September 2015. For Sweden, it was 1,903 out of 3,766 (50.5 percent). Report from the Commission to the European Parliament, the European 
Council, and the Council: Fifteenth Report on Relocation and Resettlement, $\operatorname{COM}(2017)$ 465 final, annex 3.

25. Ibid.

26. Peter Teffer, "Czechs, Hungarians, and Poles Have One Month to Start Taking Migrants," EUobserver, 26 July 2017, https://euobserver.com/migration/138619, last accessed 29 August 2020. Poland and Hungary have hosted none, the Czech Republic twelve (0.4 percent), and Slovakia sixteen (3.5 percent). The Commission has spared Austria despite its government also refusing to receive any of the 1,953 refugees it was supposed to take in under the relocation scheme. Yet Austria had accepted more than 130,000 refugees in 2015 and 2016. Moreover, it did not join Hungary and Slovakia in challenging the legality of the Council decision on the temporary relocation scheme and pledged to make places available instead. The Czech Republic and Poland, in contrast, supported Hungary and Slovakia in their lawsuit and refused to comply until the ECJ would rule on the issue. The ECJ decided on 7 September 2017 that the Council had had the authority to adopt temporary measures in emergency situations. Since the four Visegrád countries continue to defy openly the relocation decision of the Council, refusing to comply, they are likely to face financial sanctions (Börzel 2020).

27. To help Greece and other member states struggling with the influx of refugees, in March 2016 the Commission unveiled plans for a refugee emergency fund of $€ 700$ million to be disbursed over the next three years. The EU and the other member states have promised to provide twenty-three hundred experts and to foot most of the $€ 300$ million for Greece to establish the necessary administrative and legal procedures for registering refugees and processing their asylum request, as well as to turn its already ill-equipped hot spots (asylum processing facilities) into proper reception facilities and detention centers (Börzel 2020).

28. After a five-year suspension, Germany restarted sending back migrants to Greece in August 2017, https://euobserver.com/migration/138700, last accessed 28 August 2020.

29. Council Decision (EU) 2015/1601 of 22 September 2015 establishing provisional measures in the area of international protection for the benefit of Italy and Greece.

30. "International Protection: Provisional Measures for the Benefit of Italy and Greece," Legislative Observatory, European Parliament, http://www.europarl.europa.eu/oeil/popups/ficheprocedure.do?lang=en\&reference=2015/0209(NLE), last accessed 10 June 2020.

31. Compare the amendments the European Parliament had proposed, http://www. europarl.europa.eu/sides/getDoc.do?type $=$ REPORT\&reference $=$ A8-2016-0236\&langu age=EN (last accessed 24 July 2020), with the Council Decision (EU) 2016/1754 of 29 September 2016 amending Decision (EU) 2015/1601 establishing provisional measures in the area of international protection for the benefit of Italy and Greece.

32. Nikolaj Nielsen, “Computer to Make EU Asylum Decisions," EUobserver, 4 May 2016, https://euobserver.com/migration/133341, last accessed 28 August 2020.

33. Ursula von der Leyen, A Union That Strives for More: My Agenda for Europe, https:// ec.europa.eu/commission/sites/beta-political/files/political-guidelines-next-commis sion_en.pdf, last accessed 30 March 2020.

34. Standard Eurobarometer 87-Wave EB87.3-TNS opinion \& social, http://ec. europa.eu/commfrontoffice/publicopinion/index.cfm/Survey/getSurveyDetail/instruments/ STANDARD/surveyKy/2142, p. 35, last accessed 3 August 2020.

\section{CONCLUSION. THE LIMITS OF REGULATORY GOVERNANCE}

1. In 2003, however, Regulation 1/2003 abolished the Commission's previous monopoly on applying many of the EU competition rules, with the aim of sharing the enforcement activities and responsibilities with the member states' national competition authorities and national courts.

2. "State Aid: Commission Refers Ireland to Court for Failure to Recover Illegal Tax Benefits from Apple Worth up to $€ 13$ Billion," European Commission press release, 
Brussels, 4 October 2017, http://europa.eu/rapid/press-release_IP-17-3702_en.htm. The Commission withdrew the case in September 2018 after Apple had repaid the fiscal payments plus interest.

3. "European Commission Withdraws ECJ Case against Ireland after €13.1 Billion Apple Tax Is Recovered," thejournal.ie, 18 October 2018, https://www.thejournal.ie/euro pean-commission-apple-tax-court-case-4293555-Oct2018/.

4. European Commission, "Excessive Deficit Procedures-Overview," https://ec.europa. eu/info/business-economy-euro/economic-and-fiscal-policy-coordination/eu-economicgovernance-monitoring-prevention-correction/stability-and-growth-pact/correctivearm-excessive-deficit-procedure/excessive-deficit-procedures-overview_en, last accessed 8 September 2019.

5. “Q\&A: Excessive Deficit Procedure without Fines?”, Hertie School, Jacques Delors Centre, 29 July 2016, http://www.delorsinstitut.de/2015/wp-content/uploads/2016/07/ 20160729_Excessive-deficit-Brinke-AB.pdf.

6. European Commission, "A New EU Framework to Strengthen the Rule of Law," $\operatorname{COM}(2014) 158$.

7. European Commission, "Upholding the Rule of Law," http://ec.europa.eu/justice/ effective-justice/rule-of-law/index_en.htm, last accessed 12 June 2017.

8. European Commission, "Commission Presents European Pillar of Social Rights and Launches Reflection on the Social Dimension of Europe by 2025," press release, 26 April 2017, http://europa.eu/rapid/press-release_MEX-17-1116_en.htm.

9. A few months later, the ECJ confirmed that the Polish retirement provisions for the supreme court as well as ordinary judges broke EU law: see Eszter Zalan, "Commission Takes Poland to Court on Eve of Election," 11 October 2019, http://euobserver.com/ political/146234, last accessed 28 August 2020.

10. Eszter Zalan, "EU Action of Hungary and Poland Drowns in Procedure," EUobserver, 13 November 2018, http://euobserver.com/political/143359, last accessed 28 August 2020.

11. Eszter Zalan, "Commission Takes Poland to Court on Eve of Election," EUobserver, 11 October 2019, http://euobserver.com/political/146234, last accessed 28 August 2020.

12. Andrew Rettmann, "EU Court Blocks Poland's Bid to 'Frighten' Judges," 9 April 2020, https://euobserver.com/justice/148033, last accessed 28 August 2020.

13. Sam Morgan, "EU Bans Logging in Poland's Primeval Forest," Euractiv, 31 July 2017, https://www.euractiv.com/section/energy-environment/news/eu-court-bans-logging-inpolands-primeval-forest/, last accessed 28 August 2020.

14. Jack Ewing, "E.U. Commission Approves Billions in Aid for 2 Italian Banks," New York Times, 25 June 2017, https://www.nytimes.com/2017/06/25/business/eu-italy-bankspopolare-veneto.html, last accessed 28 August 2020. 